\title{
Faktor Yang Mempengaruhi Wisatawan Untuk Menikmati Wisata Minat Khusus ( Study kasus Goa Cerme )
}

\author{
M. Fathurrahman Nurul Hakim ${ }^{1)}$, Dhimas Setyo Nugroho ${ }^{2)}$ \\ Universitas Bina Sarana Informatika \\ E-Mail : fathurrahman.mfh@bsi.ac.id ${ }^{1)}$, dhimas42@gmail.com ${ }^{2)}$
}

\begin{abstract}
This research is focused on finding and multiplying factor that influence tourists to enjoy special interest tour taken from sampling Cerme Cave attractions Enjoying Tourism Special interests require strong courage and determination, where this tour uses a lot of andrenaline, so it requires special preparation to carry out this tour going well, In Goa Cerme tourists will be treated to a special interest tour that is walking in Cave (Caving) with a distance of cave the trip is almost $1.5 \mathrm{KM}$ with an average water depth of $1 \mathrm{M}$ in the cave will be found very interesting rocks. This study uses a qualitative descriptive method so that researchers must be observant in multiplying information documenting and focusing on analyzing factors that influence tourists to enjoy special interest tours. From this study, it can be concluded that the factors influencing tourists to enjoy special Adventure Tourism, challenges, the beauty of the panorama presented, the ease of access obtained, the safety of tourists in enjoying this special interest tour.
\end{abstract}

\section{Keywords: Factors, Influence, Special Adenture Tourism}

Abstrak - Penelitian ini difokuskan untuk mencari faktor yang mempengaruhi wisatawan untuk berkunjung dan menikamati wisata minat khusus mengambil data dari Goa Cerme. Menikmati Wisata Minat khusus di perlukan keberanian dan tekad yang kuat, dimana wisata ini banyak mengunakan andrenalin, sehingga memerlukan persiapan yang khusus guna pelaksanaan wisata ini berjalan dengan baik, Di Goa Cerme wisatawan akan di suguhi wisata minat khusus yaitu susur Goa dengan lorong goa yang jarak tempuhnya hampir $1.5 \mathrm{KM}$ dengan kedalaman air rata -rata $1 \mathrm{M}$ didalam goa akan banyak ditemukan berbatuan yang sangat menarik. Penelitian ini mengunakan metode Deskriptif Kualitatif sehingga peneliti harus jeli dalam mengali informasi mendokumentasi dan fokus menganalisis pada Faktor yang memepengaruhi wisatawan menikmati wisata Minat Khusus. Dari penelitian ini, dapat disimpulkan bahwa faktor yang mempengaruhi wisatawan menikmati wisata minat khusus adalah, tantangan, keindahan panorama yang di sajikan, kemudahan akses yang didapatkan, Keamanan wisatawan dalam menikmati wisata minat khusus ini.

Kata Kunci : Faktor, Pengaruh, Wisata Minat Khusus

\subsection{Latar Belakang}

Kabupaten Bantul merupakan salah satu dari 5 wilayah di Daerah Istimewa Yogyakarta. Ibukota Kabupaten Bantul adalah Bantul, yang berjarak sekitar $10 \mathrm{~km}$ kearah selatan kota Yogyakarta. Kabupaten Bantul terletak antara $07^{\circ} 44^{\prime} 04^{\prime \prime}-08^{\circ} 00^{\prime} 27^{\prime \prime}$ LS dan $110^{\circ} 12^{\prime} 34^{\prime \prime}-110^{\circ} 31^{\prime} 08^{\prime \prime}$ BT. Memiliki luas wilayah sekitar 506,85 km², Kabupaten Bantul berbatasan dengan Kabupaten Sleman di sebelah Utara, Kabupaten Kulonprogo di sebelah Barat, Kabupaten Gunung Kidul di sebelah Timur, dan Samudera Hindia di sebelah Selatan. Keadaan alam bantul ditandai dengan 3 ciri lingkungan, yakni kawasan dataran rendah, kawasan perbukitan, dan kawasan pantai.

Kabupaten Bantul memiliki motto " Projotamansari " singkatan dari produktif, profesional, ijo royo-royo, tertib, aman, sehat dan asri, sejahtera dan demokratis. Kabupaten Bantul mempunyai potensi obyek wisata yang cukup besar, yang meliputi obyek wisata alam, wisata budaya/sejarah, pendidikan, taman hiburan dan sentra industri kerajinan. Dengan keanekaragaman potensi wisata tersebut diharapkan Kabupaten Bantul dapat secara optimal mendukung pengembangan Daerah Istimewa Yogyakarta sebagai daerah tujuan wisata utama di Indonesia.

Kabupaten Bantul juga sering menggelar acara tahunan di berbagai tempat, seperti Festival layang-layang di Pantai Parangkusumo, Festival Perahu Naga di Pantai Glagah Indah, Paralayang di Pantai Depok, Bantul Expo di Pasar Seni Gabusan, dan masih banyak lagi acara-acara di Kabupaten Bantul ini.

Goa cerme pada awalnya adalah tempat pertemuan yang digunakan oleh Walisongo untuk menyebarkan dan mengajarkan agama islam di Jawa. Kata "Cerme" berasal dari kata "ceramah", pembicaraan yang diadakan selama pertemuan dalam membahas rencana mendirikan Masjid Besar di Demak.

Terletak di Desa Selopamioro,sekitar 30 $\mathrm{km}$ tenggara kota Yogyakarta. Panjang goa seluruhnya $\pm 1,5 \mathrm{~km}$, dengan rata-rata 
kedalaman air sekitar 1-1,5 m. Mulut goa berada di Dusun Srunggo, Selopamioro, Imogiri, Bantul. Sedang ujungnya berada di Dusun Ploso, Giritirto, Panggang, Gunungkidul. Di dalam Goa Cerme terdapat beberapa goa kecil yang biasa digunakan untuk bersemedi, antara lain Goa Dhalang, Goa Ledhek, Goa Badhut, dan Goa Kaum.

Untuk mencapai gerbang depan goa, wisatawan harus mendaki $759 \mathrm{~m}$ tangga. Daya tarik utama dari Goa Cerme ini adalah keindahan stalagtit dan stalagmit serta adanya sungai bawah tanah. Kondisi di dalam goa tanpa lampu penerangan gelap gulita dan lantai goa digenangi oleh air tanah, yang pada musim penghujan airnya akan pasang/naik, tetapi pada musim kemarau airnya surut. Pada umumnya,

Goa Cerme ini tak kalah indahnya dengan tempat-tempat wisata alam lainnya. Selain masih alami, Goa Cerme ini sudah mempunyai fasilitas-fasilitas yang mendukung, seperti tempat parkir, tempat ibadah (mushola), bangunan joglo ( tempat untuk istirahat), warung makan dan Toilet umum.

Meskipun tempat ini masih terlihat alami dan tampak indah, tetapi tak banyak wisatawan yang berkunjung ketempat ini. Biasanya wisatawan yang berkunjung rata-rata karena mereka suka dengan petualangan. Wisatawan dapat menikmati sungai bawah tanahnya dengan caving ( susur goa). Selain itu karena Goa Cerme ini berbeda dengan goa-goa lainnya atau bisa juga disebut dengan wisatawan minat khusus.

Di Goa Cerme ini kita dapat mengikuti acara-acara yang diadakan secara rutin. Agenda rutin atraksi wisata di Goa Cerme adalah Upacara Jodhangan yang diselenggarakan oleh Masyarakat Srunggo, Selopamioro.Upacara ini rutin diadakan setiap Minggu Pahing Bulan Besar atau Sura, kalender Jawa.

Keberagaman minat wistawan untuk berkunjung di obyek wisata menuntut pengelola tempat wisata agar dapat memenuhi kebutuhan wisatawan tersebut maka bermunculan teori - teori tentang jenis Pariwisata.

Menurut pendit , (1994) ada beberapa jenis pariwisata yang sudah dikenal, antara lain

1. Wisata Budaya yaitu perjalanan yang dilakukan atas dasar keinginan untuk memperluas pandangan hidup seseorang dengan jalan mengadakan kunjungan ke tempat lain atau ke luar negeri, mempelajari keadaan rakyat, kebiasan dan adat istiadat, cara hidup, kebudayan dan seni mereka.
2. Wisata Kesehatan yaitu perjalanan seseorang wisatawan yang bertujuan untuk menukar keadaan dan lingkungan tempat sehari-hari dimana ia tinggal demi kepentingan beristirahat baginya dalam arti jasmani dan rohani.

3. Wisata Olahraga yaitu wisatawan yang melakukan perjalanan dengan tujuan untuk berolahraga atau memang sengaja untuk mengambil bagian aktif dalam pesta olahraga di suatu tempat atau Negara.

4. Wisata Komersial yaitu wisatawan yang melakukan perjalanan untuk mengunjungi pameran-pameran dan pekan raya yang bersifat komersial seperti pameran industri, pameran dagang dan sebagainya.

5. Wisata Industri yaitu perjalanan yang dilakukan oleh rombongan mahasiswa atau pelajar, atau orang-orang awam ke suatu tempat perindustrian dengan maksud dan tujuan untuk mengadakan penelitian.

6. Wisata Bahari yaitu perjalanan yang banyak dikaitkan dengan olahraga air seperti danau, pantai atau laut.

7. Wisata Cagar Alam yaitu jenis wisata yang biasanya banyak diselenggarakan oleh agen atau biro perjalanan yang mengkhususkan usaha-usaha dengan mengatur wisata ke tempat atau daerah cagar alam, Taman lindung, hutan daerah pegunungan dan sebagainya, yang kelestariannya dilindungi oleh UndangUndang.

8. Wisata Bulan Madu yaitu suatu perjalanan yang dilakukan bagi pasangan pengantin baru yang sedang berbulan madu dengan fasilitas-fasilitas khusus dan tersendiri demi kenikmatan perjalanan.

Dari penelitan awal maka penulis mengambil penelitian tentang Faktor-faktor yang mempengaruhi wisatawan menikmati wisata khusus dengan sample Goa Cerme selopamiro Bantul.

\subsection{Tinjauan Pustaka}

\subsubsection{Pengertian Pariwisata}

Menurut Arjuna, (2016) Pariwisata berasal dari bahasa sansekerta, pari = sempurna, lengkap, tertinggi, wisata = perjalanan, sehingga pariwisata berarti perjalanan yang lengkap/sempurna. Pariwisata adalah berbagai macam kegiatan wisata dan didukung berbagai fasilitas serta layanan yang disediakan oleh masyarakat, pengusaha, pemerintah dan pemerintah daerah.( UU No. 10 Tahun 2009 Pasal 1 ayat 3 ) 
Menurut Pendit (1994) Unsur-unsur yang terlibat dalam industri pariwisata meliputi hal-hal sebagai berikut

1. Akomodasi, tempat seseorang untuk tinggal sementara.

2. Jasa Boga dan Restoran, industri jasa di bidang penyelenggaraan makanan dan minuman yang dikelola secara komersial.

3. Transportasi dan Jasa Angkutan, industri usaha jasa yang bergerak di bidang angkutan darat, laut dan udara.

4. Atraksi Wisata, kegiatan wisata yang dapat menarik perhatian wisatawan atau pengunjung.

5. Cinderamata ( Souvenir), benda yang dijadikan kenang-kenangan untuk dibawa oleh wisatawan pada saat kembali ke tempat asal.

6. Biro Perjalanan, badan usaha pelayanan semua proses perjalanan dari berangkat hingga kembali.

\subsubsection{Faktor Budaya}

Menurut Kotler (2005) Kebudayaan merupakan penentu keinginan perilaku yang paling mendasar untuk mendapatkan nilai, persepsi, preferensi dan perilaku dari lembaga -lembaga lainnya. Faktor Kebudayaan mempunyai pengaruh yang paling luas dan paling dalam terhadap perilaku konsumen.

Faktor penarik, yaitu hal yang dapat menarik minat seseorang sehingga orang tersebut mau bekerja atau bertindak.( http://www.pengertian-faktor-menurut -KBBI. com, tanggal akses 10 Juli 2018)

\subsubsection{Pengaruh}

Pengertian Pengaruh menurut Kamus besar Bahasa Indonesia (2001: 849) Yaitu : “ Pengaruh adalah daya yang ada atau timbul dari sesuatu (orang atau benda) ikut membentuk watak, kepercayaan dan perbuatan seseorang". Sedangkan Pengertian menurut Badudu dan Zain (2001) Pengaruh adalah :

1. Daya yang menjadikan sesuatu Terjadi

2. Sesuatu yang dapat membentuk atau mengubah sesuatu yang lain.

3. 3.Tunduk atau mengikuti karena kuasa atau kekuatan orang lain.

Dari pengertian diatas dapat di ambil kesimpulan bahwa pengaruh merupakan sumber daya yang dapat mengubah dan membentuk sesuatu yang berbeda

\subsubsection{Wisatawan}

Menurut Gamal (2004) Seseorang atau kelompok orang yang melakukan suatu perjalanan wisata disebut dengan wisatawan ( tourist ), jika lama tinggalnya sekurangkurangnya 24 jam di daerah / negara yang dikunjungi. Apabila mereka tinggal di daerah / negara yang dikunjungi dengan waktu kurang dari 24 jam maka mereka disebut pelancong (excursionist).

Wisatawan adalah setiap orang yang datang dari suatu negara yang alasannya bukan untuk menetap atau bekerja di situ secara teratur, dan yang di negara dimana ia tinggal untuk sementara itu membelanjakan uang yang didapatkannya di lain tempat ( Yoeti, 1995)

Menurut Yoeti (1995), Berdasarkan sifat perjalanan dan ruang lingkup perjalanan wisatawan dapat dikelompokkan sebagai berikut :

1. Wisatawan Asing ( Foreign Tourist) adalah orang asing yang melakukan perjalanan wisata, yang datang memasuki negara lain yang bukan negara asalnya.

2. Wisatawan Asing Domestik ( Foreign Domestic Tourist ) adalah wisatawan asing yang berdiam di suatu negara yang melakukan perjalanan wisata di wilayah negara dimana ia berdiam.

3. Wisatawan Domestik (Domestic Tourist) adalah warga suatu negara yang melakukan perjalanan wisata dalam batas wilayah negaranya sendiri.

4. Wisatawan Domestik Asing ( Indigenous Tourist ) adalah warga suatu negara tertentu, yang karena tugasnya di luar negeri, pulang ke negara asalnya dan melakukan perjalanan wisata di wilayah negara asalnya.

5. Wisatawan Transit ( Transit Tourist) adalah wisatawan dalam perjalanan wisata ke suatu negara tertentu yang terpaksa singgah di suatu negara bukan atas kemauannya sendiri.

6. Wisatawan Bisnis ( Business Tourist) adalah orang ( baik orang asing maupun warga negara sendiri ) yang melakukan perjalanan bukan dengan tujuan sebagai wisata, tetapi perjalanan wisata akan dilakukan setelah tujuan utama selesai.

\subsubsection{Wisata minat khusus.}

Wisata minat khusus yaitu Kekhususan pada objeknya, bisa Alam ataupun Budayanya dalam wisata minat khusus terdapat varian antara pasif dan aktif, Untuk yang pasif Wisatawan menerima sajian dalam arti menikmati suatu lingkungan alam yang mengagumkan dan langka. Sedangkan yang Aktif, Wisatawan melakukan sesuatu kegiatan yang terkait dengan objeknya seperti Arum Jeram dll. (Yoeti, 2016)

\subsection{Metode Penelitian}

Metode penelitian mengunakan metode deskritif kualitatif yaitu peneliti berusaha mengambarkan sesuatu gejala sosial yang tengah berlangsung saat penelitian, peneliti 
kualitatif yang menerapkan sudut padang ini berusaha menginterprestasikan kejadian dan peristiwa sosial sesuai dengan sudut padang dari objek penelitannya. Dalam penelitian kualitatif, peneliti sebagai instrument penelitiannya yang mana sebagai intrument penelitianya, peneliti harus memiliki teori dan pengetahuan luas, mampu bertanya, menganalisa, mendokumentasikan dan mengkontruksi situasi sosial objek yang diteliti menjadi lebih jelas dan bermakna ada beberapa tahapan yang dilakukan :

1. Tahap orientasi ( Pengenalan/Deskripsi)

Peneliti mendeskripsikan apa yang dia lihat, didengar dan dirasakan serta di tanyakan, pengenalan sepintas terhadap informasi yang di peroleh.

2. Tahap Reduksi/Fokus,

Pada proses reduksi peneliti mereduksi data yang di temukan dan memfokuskan pada masalah tertentu.

3. Tahap Selection,

Peneliti menguraikan fokus yang telah di tetapkan menjadi lebih rinci dan melakukan analisis yang lebih mendalam terhadap data dan informasi yang di peroleh, juga mampu menghasilkan informasi - informasi yang bermakna. Sehingga akan mempermudah untuk menganalisi terhadap faktor temuannya yang berada di objek wisata tersebut.

\subsection{Pembahasan}

1.1.1. Faktor-faktor Penunjang Daya Tarik Wisatawan Terhadap Goa Cerme

Dari hasil penelitian faktor penunjang daya tarik wisatawan meliputi :

1. Ornament Goa

Ornament berasal dari kata ornare (bahasa latin) yang berarti menghiasi, dalam ensiklopedia Indonesia p. 1017, ornament adalah setiap hiasan bergaya geometric atau yang lainnya. Ornament goa cerme yaitu adanya stalagtit dan stalagmite serta adanya sungai bawah tanah dan banyaknya kelelawar di dalam goa. Stalagtit yaitu bila batuan dalam sebuah goa terlihat menggantung kebawah dari langit-langit goadan bentuknya mengerucut, mengecil kebawah, panjangnya tergantung tetesan air yang mengucur diatasnya, ada yang menjuntai hingga 1 meter atau lebih atau kurang dari itu, dengan ujung-ujungnya yang runcing. Stalagmite yaitu bila batuan tersebut membentuk gunung-gunung kecil dan bentuknya juga tidak sama, ada yang tinggi danada juga yang rendah, dan terkadang antara stalagtit dan stalagmite "bertemu" dan membentuk tiang-tiang batu pada goa tersebut.

2. Keindahan panorama alam lingkungan sekitar

Keindahan alam lingkungan sekitar goa cerme yang rindang, sejuk, jauh dari perkotaan yang suasananya masih sangat alami, dengan suasana pedesaan membuat wisatawan tertarik untuk mengunjunginya.

3. Harga Tempat Pemungutan Retribusi

Harga TPR objek wisata goa cerme ini termasuk sangat murah. Hanya dengan Rp. 5000,-/orang wisatawan dapat menikmati keindahan goa cerme.

4. Pemandu Wisata

Selain harga TPR yang sangat murah, goa cerme juga memiliki pemandu wisata. Hanya dengan Rp. 35.000,- dengan maksimal 15 peserta, wisatawan dapat mengetahui semua sejarah tentang goa cerme.

\subsubsection{Faktor-faktor Penghambat Daya Tarik Wisatawan Terhadap Goa Cerme}

Dari hasil penelitian yang didapat, faktor penghambat daya tarik wisatawan meliputi :

1. Lokasi yang sulit dicari

Lokasi goa cerme yang lumayan jauh dari perkotaan, dan kurangnya petunjuk arah sehingga wisatawan sedikit kesulitan untuk menemukannya.

2. Akses jalan

Akses jalan untuk menuju ke goa cerme masih sempit dan menanjak membuat wisatawan sulit melewatinya .

3. Minimnya fasilitas

Fasilitas yang disediakan sudah ada seperti tempat ibadah, Toilet umum, tempat istirahat, tetapi jumlah fasilitas kurang banyak dan kurang lengkap serta kebersihan yang belum terjaga dengan baik.

4. Kebersihan

Kurangnya kepedulian wisatawan dan minimnya tempat sampah sehingga banyak wisatawan yang membuang sampah sembarangan yang menyebabkan obyek wisata ini terlihat kotor.

\subsection{Kesimpulan Dan Saran}

5.1.1. Kesimpulan

Berdasarkan hasil penelitian dan pembahasan pada bab sebelumnya, maka dapat disimpulkan bahwa :

1. Wisatawan mendapatkan informasi melalui orang lain secara langsung.

2. Wisatawan sulit menemukan lokasi goa cerme 
3. Wisatawan tertarik berkunjung ke goa cerme karena ornament goa yang membedakan dengan obyek wisata lainnya

4. Akses jalan yang kurang memadai membuat wisatawan kesulitan untuk menempuh jarak ke lokasi goa cerme

5. Kualitas pelayanan yang kurang baik dan ramah

\subsubsection{Saran}

Dari kesimpulan diatas maka sebaiknya

1. Perbaikan akses menuju Goa Cerme hendaklah di perbaiki sehingga memudahkan wisatawan menuju objek wisata tersebut.

2. Fasilitas keamanan pribadi perlu di perbaharuin guna kebutuhan keamanan wisatawan seperti Helm, lampu senter dan pelampung.

3. Kebersihan lingkungan wisata Goa Cerme perlu di tingkatkan guna kenyamanan wisatawan dan Masyarakat di sekiatrnya.

4. Peningkatkan promosi secara visual maupun audio visual serta mengunakan jejaring sosial untuk menarik wisatawan.

\section{Daftar Pustaka}

[1] Arjuna, I Gusti Bagus, 2015. Geografi Pariwisata dan Ekonomi Kreatif. Jakarta: Rajagrafindo Persada

[2] Badudu.J.S. dan Sutan Mohammad Zain. 1994. Kamus Umum Bahasa Indonesia. Jakarta: Pustaka Sinar harapan, Cetakan I

[3] Kotler, philip dan Kevin lane , 2008 Manajemen Pemasaran edisi ketiga belas. jilid I. Jakarta : Erlangga.

[4] Pendit, Nyoman S. 1994. Ilmu Pariwisata Sebuah Pengantar Perdana. Jakarta: Pradnya Paramita

[5] Suwantoro, Gamal. 2004. Dasar-dasar Pariwisata. Yogyakarta: Andi offset.

[6] Yoeti, Oka. A. 1995. Pengantar IImu Pariwisata, Jakarta: Angkasa

[7] Yoeti, Oka. A. 2016. Pariwisata Budaya, Jakarta: Balai Pustaka

[8] Dinas Kebudayaan dan Pariwisata Kabupaten Bantul. 2014. Bantul Soul Of Jiwa-Roh Java. Yogyakarta.

[9] Dinas Kebudayaan dan Pariwisata KabupatenBantul. 2014. Database Dinas Kebudayaan dan Pariwisata Kabupaten Bantul. Yogyakarta.

Sumber lain :

[10] http://www.pengertian-faktor-menurut$\mathrm{KBBI} . c o m$, di unduh tanggal 10 Maret 2016 